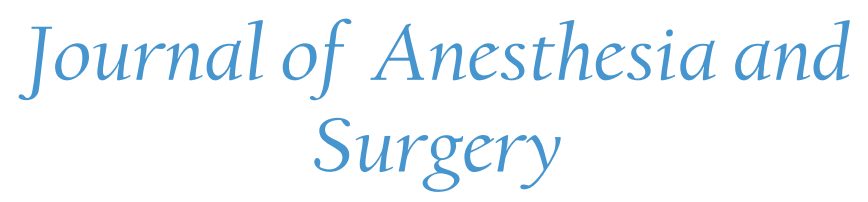

\title{
Patient Education May Improve Perioperative Safety
}

\author{
Liselotte S. De Haan ${ }^{1}$, Hiske Calsbeek ${ }^{2 *}$, André P. Wolff ${ }^{1,3}$ \\ ${ }^{1}$ Radboud University Medical Center, Department of Anesthesiology, Nijmegen, Netherlands \\ ${ }^{2}$ Radboud University Medical Center, Radboud Institute for Health Sciences (RIHS), Scientific Institute for Quality of Healthcare, \\ Nijmegen, Netherlands \\ ${ }^{3}$ University Medical Center Groningen, Department of Anesthesiology, Pain Center, Groningen, Netherlands
}

"Corresponding author: Hiske Calsbeek, Geert Grooteplein 21, 6525 EZ Nijmegen, Netherlands, Tel: 0031243668198;

E-mail: h.calsbeek@radboudumc.nl

\begin{abstract}
Importance: There is a growing interest in enabling ways for patients to participate in their own care to improve perioperative safety, but little is known about the effectiveness of interventions enhancing an active patient role.

Objective: To evaluate the effect of patient participation on perioperative safety.

Evidence review: We conducted a systematic review by searching the Cochrane, PubMed and EMBASE databases without a time limit for publications on the effect of patient-related interventions on perioperative safety. We included randomized controlled trials, quasi-experimental studies and cohort studies. The included studies were analyzed for type of intervention, safety outcomes, effects and quality.

Results: Thirteen studies were included: eight RCT's, four cohort studies and one quasi-experimental study. All studies concerned a preoperative structured educational intervention on postoperative self-management activities of patients, such as everyday movements, coughing, getting out of bed or exercising. Safety outcomes were complications, in-hospital falls and mortality. Results from eleven studies indicate positive effects of such patient-related interventions.

Conclusion and relevance: Patients appear able to improve their perioperative safety by participating in preoperative structured educational programs about postoperative regimes. Educational programs on self-management activities should be integrated in the preoperative trajectory. Further research should address the most effective components and timing of education, explore other kinds of patient involvement and link the robustness of the intervention, e.g. in terms of behavior change, to perioperative patient safety outcomes.
\end{abstract}

Received date: June 6, 2016
Accepted date: October 21, 2016
Published date: October 27, 2016

Citation: De Haan, L.S., et al. Patient Education May Improve Perioperative Safety. (2016) J Anesth Surg 3(2): 181- 189.

DOI: $10.15436 / 2377-1364.16 .047$

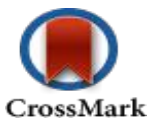

\section{Background}

About half of the adverse events (AEs) among inpatients are associated with surgical procedures ${ }^{[1,2]}$ Surgical AEs are considered preventable in more than half of the cases $(54-74 \%)^{[1]}$. Many interventions to increase perioperative patient safety address the health care process or the health care professional e.g., a surgical safety checklist ${ }^{[3,4]}$ Recently there has been more attention paid to the role patients can play regarding their own safety ${ }^{[s]}$. Patients are the only individuals physically present during every treatment and consultation. This makes them valuable to play a role in increasing the safety in their own care process ${ }^{[6]}$. Many initiatives are developed to promote patient participation aiming to improve their safety, for example "20 tips to prevent medical errors" $[7]$ and the "speak up" initiative of the Joint Commission ${ }^{[8]}$. Some have tried to identify the ways for patients to improve their own perioperative safety. For example, the Health Foundation identified five categories of patient focused interventions that could enhance patient safety; viz by involving patients in improving infection-control, increasing adherence to treatment regime, inviting them to report adverse drug events, equipping them for safer healthcare and preventing wrong-site surgery ${ }^{[5]}$. Davis et al..$^{[9]}$ tried to identify 
all of the possible interventions for surgical patients that could enhance their own safety: choosing a health care provider, undertaking a smoking cessation program, asking questions about recovery, and notifying staff when their wounds becomes infected. The timing of the intervention has been studied as well; Gillis et al. ${ }^{[10]}$ demonstrated that there was no significant difference in complication rate between prehabilitation and rehabilitation.

Although literature demonstrates that there is a huge interest in the potential for involving patients in promoting their own safety, the benefits are still unclear ${ }^{[10,11]}$. Alcohol and smoking cessation programs for which several systematic reviews have been performed ${ }^{[12-16]}$ have shown that preoperative cessation decreases the risk of post-operative complications. We therefore aimed to review the literature on the effect of other patient-related interventions that stimulate an active role of the patient to improve surgical patient safety and to generate recommendations with respect to the interventions that are proven effective in increasing perioperative safety.

\section{Methods}

\section{Data sources}

We searched for English or Dutch published studies, using the Cochrane Library, EMBASE and PubMed databases, without publication year limitations. The references of the included studies were manually checked to identify additional relevant studies that were missed in the initial database search. "Appendix 1" and "Appendix 2:" provides a detailed list of search strings.

\section{Selection of studies}

Two authors ( $\mathrm{LH}$ and $\mathrm{HC}$ ) independently assessed inclusion eligibility of the studies by title and abstract. If there was no abstract available only the title was assessed. Differences in inclusion eligibility were solved by discussion. Full text articles were retrieved for the eligible studies. The initial agreement of the two authors on full text retrievement was $96.4 \%$. For the final selection full text copies were examined to determine whether they fulfilled the inclusion criteria. Disagreement was settled by discussion with the third author (AW).

The studies had to meet four inclusion criteria. First, the participants had to be surgical patients. Second, the study needed to investigate the effect of interventions regarding active involvement of patients, potentially with help of a health care professional. Third, the outcome had to be related clearly to safety and should be appropriately reported. Following the IOM definition we described safety as the prevention of harm to patients ${ }^{[17]}$. We thus searched for safety outcomes such as adverse events, medication errors and complications. Side effects such as nausea, vomiting and difficulty to swallow were not considered to be safety related and therefore excluded. Finally, the full text had to be written in English or Dutch and should be available. Studies addressing alcohol and smoking cessation programs were excluded because of the availability of systematic reviews. After evaluating the full text articles, a manual cross-reference search of eligible articles obtained for full-text evaluation was undertaken.

\section{Quality assessment}

The included full text articles were assessed for meth- odological quality by LH and HC, disagreement was settled by discussion. The Cochrane Groups pre-designed table ${ }^{[18]}$ was used and modified to ensure standardized scoring for all included studies and to summarize their quality. The quality criteria included randomization, allocation, blinding, similarity of groups, and description of inclusion and exclusion criteria, power analysis, and intention to treat analysis and lost to follow up characteristics. Studies scored 1 point for each fulfilled criterion. If a criterion was not applicable, the item was labeled "NA". If the information was unclear or not reported, the item was labeled "No", both resulting in zero points.

\section{Data extraction and analysis}

Data were extracted from the included studies. First, descriptive characteristics such as year of publication, design, country, and type of surgery were collected. Second, the data for analysis were retrieved. We described the number of participants, the intervention, the relevant outcome and statistical significance.

\section{Results}

\section{Search results}

In total 1,984 references were retrieved by the searches (Figure 1). Forty-six references were identified as potentially relevant and 13 studies met the inclusion criteria. Reasons for exclusion were: inappropriate study design to measure intervention effect $(n=6)$, the intervention did not involve active patient participation $(\mathrm{n}=8)$, the outcome was not related to safety $(\mathrm{n}=$ $10)$ or was not clearly described $(n=3)$ and no possibility for obtaining a full text copy $(n=6)$. Checking the references of the included studies did not yield additional studies.

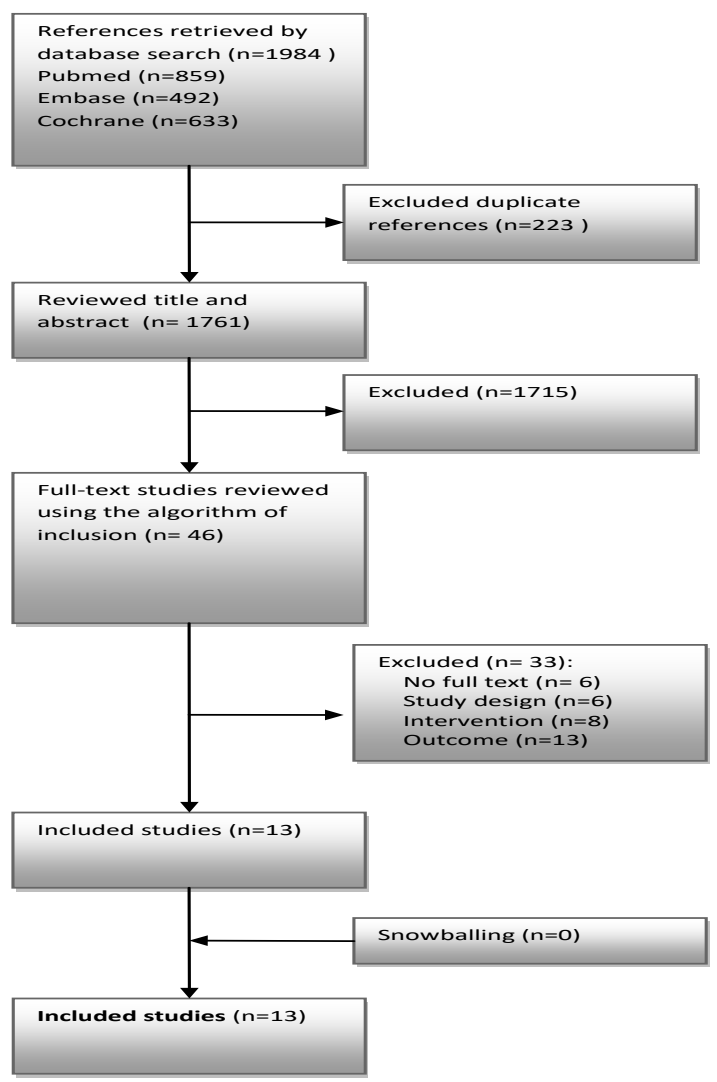

Figure 1: Flow chart of identification of relevant studies. 


\section{Characteristics of the included studies}

Background characteristics: Thirteen individual studies were included: eight randomized controlled trials, one quasi-experimental study and four cohort studies (Table 1). The majority of the studies were conducted in North America (six in the USA and two in Canada). All studies concerned adult patients. The sample sizes ranged from 12 to 656 in the intervention group and from 20 to 1,945 in the control group. The majority of the studies included patients undergoing orthopedic surgery and cardiothoracic surgery.

Table 1: Characteristics, intervention and results of included studies.

\begin{tabular}{|c|c|c|c|c|c|c|c|c|c|c|}
\hline \multirow{2}{*}{$\begin{array}{l}\text { Year, } \\
\text { Author } \\
\text { (refer- } \\
\text { ence) }\end{array}$} & \multirow[t]{2}{*}{ Design } & \multirow{2}{*}{$\begin{array}{l}\text { Coun- } \\
\text { try }\end{array}$} & \multirow{2}{*}{$\begin{array}{l}\text { Type of } \\
\text { surgery }\end{array}$} & \multicolumn{2}{|c|}{ Participants, $\mathrm{n}$} & \multirow[t]{2}{*}{ Intervention } & \multicolumn{3}{|l|}{ Results } & \multirow{2}{*}{$\begin{array}{l}\text { Signifi- } \\
\text { cance }\end{array}$} \\
\hline & & & & $\begin{array}{l}\text { Inter- } \\
\text { vention } \\
\text { group }\end{array}$ & $\begin{array}{l}\text { Control } \\
\text { group }\end{array}$ & & \multicolumn{3}{|c|}{$\begin{array}{l}\text { Outcome } \\
\text { Control n(\%) }\end{array}$} & \\
\hline $\begin{array}{l}2013, \\
\text { Mayich } \\
\text { D.J. }{ }^{[20]}\end{array}$ & $\mathrm{RCT}$ & $\begin{array}{l}\text { Cana- } \\
\text { da }\end{array}$ & $\begin{array}{l}\text { Ankle Frac- } \\
\text { ture surgery }\end{array}$ & 20 & 20 & $\begin{array}{l}\text { Information pack- } \\
\text { age containing an } \\
\text { educational handout } \\
\text { and a handout about } \\
\text { self-administered } \\
\text { physiotherapy }\end{array}$ & $\begin{array}{l}\text { Complica- } \\
\text { tions }\end{array}$ & $4(20 \%)$ & $2(10 \%)$ & $\begin{array}{l}\text { Not sig- } \\
\text { nificant } \\
\text { P } 0.22\end{array}$ \\
\hline $\begin{array}{l}\text { 2012, } \\
\text { Clarke } \\
\text { H.D. }{ }^{[22]}\end{array}$ & $\begin{array}{l}\text { Cohort } \\
\text { study }\end{array}$ & USA & $\begin{array}{l}\text { Total knee } \\
\text { arthroplasty }\end{array}$ & 72 & 172 & $\begin{array}{l}\text { Pre-operative } 15-30 \\
\text { minutes education- } \\
\text { al program that } \\
\text { addresses fall-pre- } \\
\text { vention including a } \\
\text { patient educational } \\
\text { sheet within } 14 \text { days } \\
\text { before surgery }\end{array}$ & $\begin{array}{l}\text { In-hospital } \\
\text { falls }\end{array}$ & $0(0 \%)$ & $7(4.1 \%)$ & $\begin{array}{l}\text { Signifi- } \\
\text { cant : } \\
\text { P } 0.03\end{array}$ \\
\hline $\begin{array}{l}2011, \\
\text { Kearney } \\
M .^{[28]}\end{array}$ & $\begin{array}{l}\text { Cohort } \\
\text { study }\end{array}$ & USA & $\begin{array}{l}\text { Elective } \\
\text { single joint } \\
\text { total hip } \\
\text { or knee re- } \\
\text { placement }\end{array}$ & 88 & 62 & $\begin{array}{l}\text { Structured pre-opera- } \\
\text { tive educational class } \\
\text { (face to face class or } \\
\text { online) }\end{array}$ & $\begin{array}{l}\text { Complica- } \\
\text { tions }\end{array}$ & $4(4.5 \%)$ & $8(12.9 \%)$ & $\begin{array}{l}\text { Not sig- } \\
\text { nificant } \\
\text { P } 0.06\end{array}$ \\
\hline $\begin{array}{l}2009, \\
\text { Lübbeke } \\
\text { A. }{ }^{[25]}\end{array}$ & $\begin{array}{l}\text { Cohort } \\
\text { study }\end{array}$ & $\begin{array}{l}\text { Swit- } \\
\text { zer- } \\
\text { land }\end{array}$ & $\begin{array}{l}\text { Primary total } \\
\text { hip arthro- } \\
\text { plasty }\end{array}$ & 656 & 1945 & $\begin{array}{l}3 \text { hour educational } \\
\text { session including } \\
\text { muscle strengthening } \\
\text { exercises and post- } \\
\text { operative restrictions } \\
\text { of range of motion } \\
\text { instructions }\end{array}$ & $\begin{array}{l}\text { Disloca- } \\
\text { tion of the } \\
\text { hip within } \\
6 \text { months } \\
\text { after sur- } \\
\text { gery }\end{array}$ & $5(0.8 \%)$ & $41(2.1)$ & $\begin{array}{l}\text { Signifi- } \\
\text { cant } \\
\text { P } 0.02\end{array}$ \\
\hline $\begin{array}{l}2006, \\
\text { Deyir- } \\
\text { menjian } \\
\text { M. }^{[29]}\end{array}$ & $\mathrm{RCT}$ & $\begin{array}{l}\text { Leba- } \\
\text { non }\end{array}$ & $\begin{array}{l}\text { Coronary ar- } \\
\text { tery grafting }\end{array}$ & 57 & 53 & $\begin{array}{l}\text { Education session } \\
\text { and demonstration of } \\
\text { leg and respiratory } \\
\text { exercises }\end{array}$ & $\begin{array}{l}\text { Complica- } \\
\text { tions }\end{array}$ & $13(22.8 \%)$ & $9(16.98 \%)$ & $\begin{array}{l}\text { Not sig- } \\
\text { nificant } \\
\text { P } 0.34\end{array}$ \\
\hline $\begin{array}{l}2005, \\
\text { Blay N. } \\
{[6]}\end{array}$ & $\mathrm{RCT}$ & $\begin{array}{l}\text { Aus- } \\
\text { tralia }\end{array}$ & $\begin{array}{l}\text { Laparoscop- } \\
\text { ic cholecys- } \\
\text { tectomy }\end{array}$ & 41 & 52 & $\begin{array}{l}\text { Verbal education } \\
\text { about wound care, } \\
\text { diet, activity, bowel } \\
\text { management and } \\
\text { management of med- } \\
\text { ical complication }\end{array}$ & $\begin{array}{l}\text { Wound } \\
\text { infections }\end{array}$ & $1(2.4 \%)$ & $10(19.2 \%)$ & $\begin{array}{l}\text { Not } \\
\text { reported }\end{array}$ \\
\hline $\begin{array}{l}2005, \\
\text { Siggeirs- } \\
\text { dottir } \\
K^{[17]}\end{array}$ & $\mathrm{RCT}$ & $\begin{array}{l}\text { Ice- } \\
\text { land }\end{array}$ & $\begin{array}{l}\text { Total hip } \\
\text { replacement }\end{array}$ & 27 & 23 & $\begin{array}{l}\text { Pre-operative educa- } \\
\text { tion and training pro- } \\
\text { gram about post-op- } \\
\text { erative rehabilitation, } \\
\text { information brochure } \\
\text { about exercise after } \\
\text { the operation and a } \\
\text { rehabilitation scheme }\end{array}$ & $\begin{array}{l}\text { Complica- } \\
\text { tions }\end{array}$ & $\begin{array}{l}5(18.5 \%) \\
\text { Patients } \\
\text { had } 9 \\
\text { complica- } \\
\text { tions }\end{array}$ & $\begin{array}{l}11(47.8 \%) \\
\text { Patients } \\
\text { had } 12 \\
\text { complica- } \\
\text { tions }\end{array}$ & $\begin{array}{l}\text { Not sig- } \\
\text { nificant } \\
\text { P } 0.3\end{array}$ \\
\hline
\end{tabular}




\begin{tabular}{|c|c|c|c|c|c|c|c|c|c|c|}
\hline $\begin{array}{l}\text { 1997, } \\
\text { Bass } \\
\text { E.M. }{ }^{[19]}\end{array}$ & cohort & USA & $\begin{array}{l}\text { Elective } \\
\text { stoma place- } \\
\text { ment }\end{array}$ & 292 & 301 & $\begin{array}{l}\text { Stoma education and } \\
\text { stoma marking }\end{array}$ & $\begin{array}{l}\text { Early }(< \\
1 \text { month) } \\
\text { and late }(> \\
1 \text { month) } \\
\text { complica- } \\
\text { tions }\end{array}$ & $\begin{array}{l}\text { Early: } \\
68(23.3 \%) \\
\text { Late: } 27 \\
(9.3 \%) \\
\text { Total } 91 \\
(31.2 \%)\end{array}$ & $\begin{array}{l}\text { Early: } \\
95(31.6 \%) \\
\text { Late: } \\
36(12 \%) \\
\text { Total } 117 \\
(38.9 \%)\end{array}$ & $\begin{array}{l}\text { Signif- } \\
\text { icant: } \\
\mathrm{P}<0.01\end{array}$ \\
\hline $\begin{array}{l}\text { 1994, } \\
\text { Meeker } \\
\text { B.J }{ }^{[26]}\end{array}$ & $\begin{array}{l}\text { Quasi } \\
\text { experi- } \\
\text { mental }\end{array}$ & USA & $\begin{array}{l}\text { Elective gen- } \\
\text { eral surgery, } \\
\text { urological } \\
\text { surgery or } \\
\text { colorectal } \\
\text { surgery }\end{array}$ & 49 & 95 & $\begin{array}{l}\text { Structured pre-op- } \\
\text { erative teaching } \\
\text { program }\end{array}$ & Atelectasis & $\begin{array}{l}9 \\
(18.3 \%)^{*}\end{array}$ & $5(5 \%)$ & $\begin{array}{l}\text { Signifi- } \\
\text { cant** } \\
\text { P } 0.015\end{array}$ \\
\hline $\begin{array}{l}\text { 1991, Ha- } \\
\text { nucharu- } \\
\text { rnkui } \\
\text { S. }{ }^{[27]}\end{array}$ & $\mathrm{RCT}$ & $\begin{array}{l}\text { Thai- } \\
\text { land }\end{array}$ & $\begin{array}{l}\text { Pyeloli- } \\
\text { thotomy or } \\
\text { nephro-litho- } \\
\text { tomy }\end{array}$ & 20 & 20 & $\begin{array}{l}\text { Nurse led self-care } \\
\text { program, patients } \\
\text { learned and practiced } \\
\text { deep breathing, ef- } \\
\text { fective coughing, leg } \\
\text { exercises, turning, } \\
\text { changing position, } \\
\text { getting out of bed } \\
\text { and methods of pain } \\
\text { relief }\end{array}$ & $\begin{array}{l}\text { Complica- } \\
\text { tions }\end{array}$ & $1(5 \%)$ & $3(15 \%)$ & $\begin{array}{l}\text { Signifi- } \\
\text { cant } \\
\text { P } 0.01\end{array}$ \\
\hline $\begin{array}{l}1987, \\
\text { Anderson } \\
\text { E.A. }{ }^{[24]}\end{array}$ & RCT & USA & CABG & $\begin{array}{l}20 \\
\text { Infor- } \\
\text { mation } \\
20 \mathrm{In}- \\
\text { forma- } \\
\text { tion and } \\
\text { coping }\end{array}$ & 20 & $\begin{array}{l}\text { Information: detailed } \\
\text { information, watch } \\
\text { video and listen to } \\
\text { audio tape } \\
\text { Information and } \\
\text { coping: as infor- } \\
\text { mation group and } \\
\text { taught exercises by } \\
\text { watching slide show } \\
\text { and practicing }\end{array}$ & $\begin{array}{l}\text { Acute } \\
\text { postopera- } \\
\text { tive hyper- } \\
\text { tension }\end{array}$ & $\begin{array}{l}\text { Infor- } \\
\text { mation: } \\
9(45 \%) \\
\text { Informa- } \\
\text { tion and } \\
\text { coping } \\
8(40 \%)\end{array}$ & $15(75 \%)$ & $\begin{array}{l}\text { Signif- } \\
\text { icant } \\
\mathrm{P}<0.02\end{array}$ \\
\hline $\begin{array}{l}1976, \\
\text { Felton } \\
\text { G. }{ }^{[23]}\end{array}$ & RCT & USA & $\begin{array}{l}\text { Mayor sur- } \\
\text { gery }\end{array}$ & $\begin{array}{l}25 \\
\text { Experi- } \\
\text { mental } \\
12 \text { Com- } \\
\text { munica- } \\
\text { tion }\end{array}$ & 25 & $\begin{array}{l}\text { Experimental: } \\
\text { education with films, } \\
\text { photo's, postoper- } \\
\text { ative exercise and } \\
\text { breathing techniques } \\
\text { instructions Com- } \\
\text { munication group: } \\
\text { therapeutic commu- } \\
\text { nications session }\end{array}$ & $\begin{array}{l}\text { Pulmo- } \\
\text { nary or } \\
\text { circulatory } \\
\text { complica- } \\
\text { tions }\end{array}$ & $\begin{array}{l}\text { Experi- } \\
\text { mental: } 20 \\
(80 \%) \\
\text { Commu- } \\
\text { nication: } \\
7(50 \%)\end{array}$ & $24(92 \%)$ & $\begin{array}{l}\text { Not } \\
\text { reported }\end{array}$ \\
\hline $\begin{array}{l}1976, \\
\text { Fortin } \\
{[21]}\end{array}$ & RCT & $\begin{array}{l}\text { Cana- } \\
\text { da }\end{array}$ & $\begin{array}{l}\text { Elective ma- } \\
\text { jor intra-ab- } \\
\text { dominal or } \\
\text { intra-thorac- } \\
\text { ic surgery }\end{array}$ & 37 & 32 & $\begin{array}{l}\text { Structured preop- } \\
\text { erative educational } \\
\text { program includ- } \\
\text { ing respiratory en } \\
\text { muscular exercis- } \\
\text { es, techniques of } \\
\text { changing position } \\
\text { and suggestions of } \\
\text { self-care }\end{array}$ & $\begin{array}{l}\text { Re-admis- } \\
\text { sion by } \\
\text { compli- } \\
\text { cation; } \\
\text { Death }\end{array}$ & $\begin{array}{l}0(0 \%) \\
\text { Readmis- } \\
\text { sion or } \\
\text { deaths }\end{array}$ & $\begin{array}{l}0(0 \%) \mathrm{Re}- \\
\text { admission } \\
\text { or deaths }\end{array}$ & $\begin{array}{l}\text { Not } \\
\text { reported }\end{array}$ \\
\hline
\end{tabular}

*According to the authors 9 of the 49 patients had atelectasis which would sum up to $9.5 \%$

** According to the authors the difference between the two groups was not significant (P value 0.01)

Patient-related interventions: All of the included studies investigated the effect of an educational intervention addressing topics as postoperative self-management, postoperative exercise, and everyday movements after surgery and breathing techniques. Handouts were given in some studies $(\mathrm{n}=3)$, in one study the optimum stoma location was determined together with the patient and advice was given about stoma management ${ }^{[19]}$. In most studies education was given in a more or less structured manner, example by providing an educational class or a private session. In one study an additional information package was provided containing two educational handouts ${ }^{[20]}$.

Outcome measures: Safety outcomes were mortality or readmission by complications ${ }^{[21]}$ and in-hospital falls ${ }^{[22]}$. In the other studies $(n=11)$ different types of postoperative complications were measured, for example pulmonary complications ${ }^{[23]}$, acute postoperative hypertension ${ }^{[24]}$, dislocation of the hip ${ }^{[25]}$ or wound infections ${ }^{[6]}$. 


\section{Quality of the studies}

The quality of the studies included was variable (Table 2). Overall, the randomized controlled trials scored higher than the quasi-experimental or cohort studies. In all studies inclusion and exclusion criteria were specified. In three studies the intervention and control group were not comparable at baseline; In one study the ASA-score in the intervention group was higher compared to the controls ${ }^{[26]}$; In another study participants in the control group had significantly lower ASA-scores, were more often operated by more experienced surgeons and had better pre-operative function scores ${ }^{[25]}$. A third study showed an unequal distribution of stoma types in their study group ${ }^{[19]}$. None of the studies contained a power analysis nor an intention-to-treat analysis on the outcome we were studying.

Table 2: Quality assessment of included studies.

\begin{tabular}{|c|c|c|c|c|c|c|c|c|c|c|c|}
\hline & $\begin{array}{l}\text { Year, } \\
\text { Author }\end{array}$ & $\begin{array}{l}\text { Ran- } \\
\text { domi-za- } \\
\text { tion }\end{array}$ & $\begin{array}{l}\text { Alloca- } \\
\text { tion con- } \\
\text { cealed }\end{array}$ & $\begin{array}{l}\text { Simi- } \\
\text { larity of } \\
\text { groups at } \\
\text { baseline }^{1}\end{array}$ & $\begin{array}{l}\text { Inclu- } \\
\text { sion/ } \\
\text { exclusion } \\
\text { criteria } \\
\text { specified }^{1}\end{array}$ & $\begin{array}{l}\text { Assessors } \\
\text { blinded } \\
\text { to out- } \\
\text { come }\end{array}$ & $\begin{array}{l}\text { Attrition } \\
\text { rate } \\
\text { reported }\end{array}$ & $\begin{array}{l}\text { Character- } \\
\text { istics of } \\
\text { parti- } \\
\text { ci-pants } \\
\text { lost to } \\
\text { follow up } \\
\text { described }^{1}\end{array}$ & $\begin{array}{l}\text { Intention } \\
\text { to Treat } \\
\text { analy- } \\
\text { sis*1 }\end{array}$ & $\begin{array}{l}\text { Power } \\
\text { analysis } \\
\text { calculat- } \\
\text { ed }^{1 * *}\end{array}$ & $\begin{array}{l}\text { Total } \\
\text { (max- } \\
\text { imum } \\
\text { score) }\end{array}$ \\
\hline \multirow{7}{*}{$\begin{array}{l}\text { Random- } \\
\text { ized con- } \\
\text { trolled } \\
\text { trials }\end{array}$} & $\begin{array}{l}\text { 2013, May- } \\
\text { ich DJ. }\end{array}$ & Yes & Yes & Yes & Yes & Yes & Yes & No & No & No & $6(9)$ \\
\hline & $\begin{array}{l}2005 \text {, Blay } \\
\text { N. }\end{array}$ & Yes & Yes & Yes & Yes & Yes & Yes & No & No & No & $5(9)$ \\
\hline & $\begin{array}{l}\text { 2005, Sig- } \\
\text { geirsdottir } \\
\text { K. }\end{array}$ & Yes & Yes & Yes & Yes & No & Yes & No & No & No & $5(9)$ \\
\hline & $\begin{array}{l}1991, \\
\text { Hanucharu- } \\
\text { rnkui S. }\end{array}$ & Yes & Yes & Yes & Yes & No & Yes & NA & No & No & $5(8)$ \\
\hline & $\begin{array}{l}\text { 1987, An- } \\
\text { derson E.A. }\end{array}$ & Yes & No & Yes & Yes & Yes & Yes & NA & No & No & $5(8)$ \\
\hline & $\begin{array}{l}\text { 1976, Felton } \\
\text { G. }\end{array}$ & Yes & No & Yes & Yes & No & No & NA & No & No & $3(8)$ \\
\hline & 1976, Fortin & Yes & Yes & Yes & Yes & Yes & Yes & No & No & No & $6(9)$ \\
\hline \multirow{2}{*}{$\begin{array}{l}\text { Quasi- } \\
\text { expi- } \\
\text { ri-mental }\end{array}$} & $\begin{array}{l}\text { 2006, Dey- } \\
\text { irmenjian } \\
\text { M. }\end{array}$ & Yes & Yes & Yes & Yes & Yes & No & NA & No & No & $5(8)$ \\
\hline & $\begin{array}{l}\text { 1994, } \\
\text { Meeker B.J }\end{array}$ & No & No & No & Yes & No & No & NA & No & No & $1(8)$ \\
\hline \multirow{4}{*}{$\begin{array}{l}\text { Cohort } \\
\text { studies }\end{array}$} & $\begin{array}{l}\text { 2012, } \\
\text { Clarke H.D. }\end{array}$ & $\mathrm{Na}$ & NA & Yes & Yes & No & NA & No & NA & No & $2(5)$ \\
\hline & $\begin{array}{l}\text { 2011, Kear- } \\
\text { ney M. }\end{array}$ & NA & NA & Yes & Yes & No & NA & NA & NA & No & $2(4)$ \\
\hline & $\begin{array}{l}2009, \text { Lüb- } \\
\text { beke A. }\end{array}$ & NA & NA & No & Yes & Yes & Yes & No & $\mathrm{NA}^{* * *}$ & No & $3(6)$ \\
\hline & $\begin{array}{l}\text { 1997, Bass } \\
\text { E.M. }\end{array}$ & NA & NA & No & Yes & No & No & NA & NA & No & $1(5)$ \\
\hline
\end{tabular}

NA: Not applicable

Unknown or unclear was labeled as No

1: added quality criteria by authors

* The intention to prevent harm

** Power analyses of outcome of our interest

*** Number needed to treat is calculated

\section{Effects of interventions}

Five studies showed significant effects on patient safetyby decreasing the number of post-operative complications $^{[19,24,25,27]}$ or in hospital falls ${ }^{[22]}$ (Table 1). Four of these studies $^{[22,24,25,27]}$ concerned an educational intervention regarding self-care or post-operative exercises, measuring effects on hip dislocation, post-operative complications or in hospital falls.
The fifth study ${ }^{[19]}$ concerned education about stoma care, the patient learnt what a stoma was and received accurate information about living with a stoma. Together with the patient the optimum location for the stoma was marked. This intervention decreased early and overall complications but not the late complication rate. In two studies ${ }^{[6,23]}$ educating the participants in self-care or exercises seemed to improve patient safety, although the significance was not mentioned. In one study ${ }^{[21]}$ deaths or readmissions by complication did not occur and there by the effect on safety could not be evaluated.

In four studies no significant improvement in patient safety could be shown, although two of these studies ${ }^{[17,28]}$ did demonstrate a non-significant improvement. One study ${ }^{[26]}$ demonstrated an unexpected significant decrease in patient safe- 
ty; participants in a preoperative teaching program had a higher incidence of atelect as is than the non-participants. The higher ASA-score of the participants compared with the non-participants may be the reason for this.

\section{Discussion}

Our systematic review suggests that patients may influence safety outcomes after surgery if they participate in a structured educational program. Teaching patients how to move, self care, breath and exercise after surgery seems to help reduce complications, in-hospital falls and hip dislocations after surgery. All of our studied interventions involved pre-operative educational programs. The measured safety outcomes concerned several kinds of complications. In most of the studies the outcome of increased safety was not defined as a primary outcome and therefore lacked adequate power to demonstrate statistically significant effects. We therefore performed a meta-analysis including 6RCTs (excluding $2 \mathrm{RCTs}^{[21,29]}$, respectively for reasons of no complications in both the intervention and control group in one study, and presenting the number of complications instead of the number of patients with complications in another study). This meta-analysis revealed no robust statistical significance but showed that pre-operative patient education tends to reduce the occurrence of postoperative complications (RR 0.64; $95 \%$ CI $0.35-1.15 ; p=0.08)$. It must be noted that because of the different types of reported postoperative complications and types of surgery we used a random effect model instead of the default 'fixed effect model' to estimate the single risk ratios and the overall effect. Using a random effect model results in a larger confidence interval of the overall effect ${ }^{[30]}$, there by not revealing a statistical significant effect.

Our results are in line with the results of systematic reviews about smoking and alcohol cessation programs ${ }^{[12-15]}$, which demonstrate that these programs are beneficial in reducing post-operative complications. The educational programs in our review, however, varied in content because of the different surgeries, but shared a focus on aspects of postoperative self-management. Despite a lack of precise insight into the intensity of education and extent of participation of patients, we do know that the educational interventions were given by health care workers in a structured way and patients had the opportunity to practice the exercises, and proceedings were learned under supervision of an expert. Just providing patients with information sheets, without further explanation, does not seem to increase patient safety ${ }^{[20]}$.

Explanations provided for the ineffectiveness of interventions vary and include a possible lack of compliance with the given recommendations ${ }^{[20]}$, inexperienced staff $^{[20]}$, cultural differences where the physician is expected to make the decisions $^{[29]}$ and inappropriate timing of applying the intervention example the day before surgery, when patients are too apprehensive to listen ${ }^{[29]}$. One study ${ }^{[26]}$ showed an unexpected significant decrease in perioperative safety, but this effect may be attributed to a higher ASA-score in the intervention group. In addition, we found miscalculations and ambiguities in the results and therefore considered this study less reliable.

The evidence identified in our review does not address all potential areas of patient involvement in perioperative safety. For example, we did not find studies on enabling surgical patients to choose their health care worker, patients questioning hand hygiene or patient reporting of adverse drug events, examples of interventions that were suggested by the Healthcare Foundation $^{[5]}$ and Davis et al. ${ }^{[9]}$. We found some studies investigating other interventions, for example Bergal et al. ${ }^{[31]}$, who studied an intervention to prevent wrong site surgery by patients asking to mark the site of operation with "Yes". Jangland et al. ${ }^{[32]}$ studied the "Tell-us" card, which patients could use to write down their specific questions and concerns for the day of or before discharge. However, these studies did not evaluate the effect on safety outcomes and were therefore excluded from our review.

A limitation of our review method is that we searched the major databases. We did not search lesser known databases nor did we do a hand search of the journals where the included studies were published. We tried to overcome this limitation by checking the references of included articles for potential relevant studies. Also, no attempts were made at collecting unpublished data nor do we have any information about potential publication bias. On the other hand, strength of our review method is that we did not use a time limit yielding some interesting studies that otherwise would not have been included. Another limitation is that we did not systematically collect data from the included studies about behavior change, extent of participation of patients or process measures about the extent of success of the educational intervention reflecting the robustness of the intervention. Using this kind of information would have been more precise in assessing the impact on the safety outcomes of our interest.

To our knowledge, outside alcohol and tobacco cessation, no previously study has reviewed the effects of patient participation on perioperative patient safety. Based on these results, we recommend that patients should be active in their own care trajectory which can be encouraged by inviting and stimulating them to join a structured educational programon self-management activity. In this way, patients may contribute to improve their own perioperative safety.

\section{Conclusion}

Active patient participation in education programs on how to manage the postoperative situation can improve patient safety. The potential difficulties with daily activities and breathing compared to the situation before surgery should be explained. In line with the proven beneficial results of smoking and alcohol cessation program, these educational interventions may be most effective when given in a structured way, resulting in fewer in-hospital falls, hip dislocations and other post-operative complications. Future studies should address the most effective components and timing of education, explore the effects of other patient-related interventions, for example the use of patient safety cards aimed at helping patients to safeguard their perioperative care trajectory, and should link the robustness of the intervention, example in terms of behavior change, to safety outcomes, such as complications, mortality, medication errors or other adverse events.

Conflicts of Interest: Authors declare no conflicts of interest. 


\section{References}

1. Jha, A.K., Prasopa-Plaizier, N., Larizgoitia, I., et al. Patient safety research: an overview of the global evidence. (2010) Qual Saf Health Care 19(1): 42-47.

2. Weingart, S.N., Wilson, R.M., Gibberd, R.W., et al. Epidemiology of medical error. (2000) BMJ 320(7237): 774-777.

3. Haynes, A.B., Weiser, T.G., Berry, W.R., et al. A surgical safety checklist to reduce morbidity and mortality in a global population. (2009) N Engl J Med 360(5): 491-499.

4. World Alliance for Patient Safety. (2008) WHO surgical safety checklist.

5. Coulter, A. Patient-focused interventions: A review of the evidence. (2006) Picker Institute Europe.

6. Blay, N., Donoghue, J. The effect of pre-admission education on domiciliary recovery following laparoscopic cholecystectomy. (2005) Aust J Adv Nurs 22(4): 14-19.

7. AHRQ. 20 tips to prevent medical errors. (2000).

8. Joint comission on accreditation of healthcare Organistation. (2010) Speak up initiatives.

9. Davis, R.E., Sevdalis, N., Jacklin, R., et al. An examination of opportunities for the active patient in improving patient safety. (2012) J Patient Saf 8(1): 36-43.

10. Hall, J., Peat, M., Birks, Y., et al. Effectiveness of interventions designed to promote patient involvement to enhance safety: a systematic review. Qual Saf Health Care 19(5): e10.

11. Peat, M., Entwistle, V., Hall, J., et al. Scoping review and approach to appraisal of interventions intended to involve patients in patient safety. (2010) J Health Serv Res Policy 15 (Suppl 1): 17-25.

12. Moller, A.M., Villebro, N., Pedersen, T. Interventions for preoperative smoking cessation.(2014) Cochrane Database Syst Rev (3): CD002294.

13. Oppedal, K., Moller, A.M., Pedersen, B., et al. Preoperative alcohol cessation prior to elective surgery. (2012) Cochrane Database Syst Rev (7): CD008343.

14. Tonnesen, H., Nielsen, P.R., Lauritzen, J.B., et al. Smoking and alcohol intervention before surgery: evidence for best practice. (2009) $\mathrm{Br}$ J Anaesth 102(3): 297-306.

15. Thomsen, T., Tonnesen, H., Moller, A.M. Effect of preoperative smoking cessation interventions on postoperative complications and smoking cessation. (2009) Br J Surg 96(5): 451-461.

16. Gronkjaer, M., Eliasen, M., Skov-Ettrup, L.S., et al. Preoperative Smoking Status and Postoperative Complications: A Systematic Review and Meta-analysis. (2014) Ann Surg 259(1): 52-71.

17. Siggeirsdottir, K., Olafsson, O., Jonsson, H., et al. Short hospital stay augmented with education and home-based rehabilitation improves function and quality of life after hip replacement: randomized study of 50 patients with 6 months of follow-up. (2005) Acta Orthop 76(4): $555-562$.

18. Higgins, J.G. Cochrane Handbook for Systematic Reviews of Interventions. (2006) Chichester United Kingdom.

19. Bass, E.M., Del Pino, A., Tan, A., et al. Does preoperative stoma marking and education by the enterostomal therapist affect outcome? (1997) Dis Colon Rectum 40(4): 440-442.

20. Mayich, D.J., Tieszer, C., Lawendy, A., et al. Role of patient information handouts following operative treatment of ankle fractures: a prospective randomized study. (2013) Foot Ankle Int 34(1): 2-7.

21. Fortin, F., Kirouac, S. A randoimized controlled trial of preoperative patient education. (1976) Int J Nurs Stud 13(1): 11-24.

22. Clarke, H.D., Timm, V.L., Goldberg, B.R., et al. Preoperative patient education reduces in-hospital falls after total knee arthroplasty. (2012) Clin Orthop Relat Res 470(1): 244-249.

23. Felton, G., Huss, K., Payne, E.A., et al. Preoperative nursing intervention with the patient for surgery: outcomes of three alternative approaches. (1976) Int J Nurs Stud 13(2): 83-96.
24. Anderson, E.A. Preoperative preparation for cardiac surgery facilitates recovery, reduces psychological distress, and reduces the incidence of acute postoperative hypertension. (1987) J Consult Clin Psychol 55(4): 513-520.

25. Lubbeke, A., Suva, D., Perneger, T., et al. Influence of preoperative patient education on the risk of dislocation after primary total hip arthroplasty. (2009) Arthritis Rheum 61(4): 552-558.

26. Meeker, B.J. Preoperative patient education: evaluating postoperative patient outcomes. (1994) Patient Educ Couns 23(1): 41-47.

27. Hanucharurnkui, S., Vinya-nguag, P. Effects of promoting patients' participation in self-care on postoperative recovery and satisfaction with care. (1991) Nurs Sci Q 4(1): 14-20.

28. Kearney, M., Jennrich, M.K., Lyons, S., et al. Effects of preoperative education on patient outcomes after joint replacement surgery. (2011) Orthop Nurs 30(6): 391-396.

29. Deyirmenjian, M., Karam, N., Salameh, P. Preoperative patient education for open-heart patients: a source of anxiety? (2006) Patient Educ Couns 62(1): 111-117.

30. Scholten, R.J., Assendelft, W.J., Kostense, P.J., et al. [The practice of systematic reviews.V. Heterogeneity between studies and subgroup analysis]. (1999) Ned Tijdschr Geneeskd 143(16): 843-848.

31. Bergal, L.M., Schwarzkopf, R., Walsh, M., et al. Patient participation in surgical site marking: can this be an additional tool to help avoid wrong-site surgery? J Patient Saf 6(4): 221-225.

32. Jangland, E., Carlsson, M., Lundgren, E., et al. The impact of an intervention to improve patient participation in a surgical care unit: a quasi-experimental study. (2012) Int J Nurs Stud 49(5): 528-538.

\section{Appendix 1: Search strings by Database}

\section{PubMed:}

("Consumer Participation"[Mesh] OR patient participation [mesh] OR Pamphlets [Mesh] OR ("Patient Education as Topic"[Majr]) OR ( "Patient Education as Topic/education"[Mesh] OR "Patient Education as Topic/methods"[Mesh] OR "Patient Education as Topic/standards"[Mesh] OR "Patient Education as Topic/utilization"'[Mesh] )OR Consumer Health Information [Mesh] OR "Audiovisual Aids"[Mesh] OR Consumer Participation [tiab] OR Patient Participation [tiab] OR patient involvement[tiab] OR consumer involvement [tiab] OR Pamphlets [tiab] OR Consumer Health Information [tiab] OR Educational Technology [tiab] OR audiovisual aids [tiab] OR user participation [tiab] OR client participation [tiab] OR citizen participation [tiab] OR public participation [tiab] OR caregiver participation [tiab] OR parent participation [tiab] OR relative participation [tiab] OR user involvement [tiab] OR client involvement [tiab] OR citizen involvement [tiab] OR public involvement[tiab] OR caregiver involvement [tiab] OR parent involvement [tiab] OR relative involvement [tiab] OR ipad [tiab] OR handout* [tiab] ) AND ("Surgery Department, Hospital"'[Mesh] OR “Operating Rooms"[Mesh] OR "Preoperative Care"[Mesh] OR "Perioperative Care"[Mesh] OR "Postoperative Care"[Mesh] OR "Intraoperative Period"'[Mesh] OR "Postoperative Period"[Mesh] OR “Perioperative Nursing”[Mesh] OR "Anesthesia and Analgesia"[Mesh] OR Anesthetics[Mesh] OR surger*[tiab] OR surgic*[tiab] OR Operating Room[tiab] OR Operating Rooms[tiab] OR preoperative[tiab] OR preoperative [tiab] OR perioperative[tiab] OR intraoperative[tiab] OR postoperative[tiab] OR Anaesthesia [tiab] OR Anesthesia[tiab] OR Anaesthetics[tiab] OR Anesthetics[tiab] OR Analgesia[tiab] OR postanesthesia [tiab] OR Recovery room[tiab] OR 
Recovery rooms[tiab] OR PACU[tiab]) AND ("Safety"[Mesh] OR "Retreatment"[Mesh] OR "Mortality"[Mesh:noexp] OR "Fatal Outcome"[Mesh] OR "Survival Rate"[Mesh] OR "Intraoperative Complications"[Mesh] OR "Postoperative Complications"[Mesh] OR "Health Status Disparities"[Mesh] OR "Safety Management"[Mesh] OR "Medical Errors"[Mesh:NoExp] OR "Medication Errors"[Mesh] OR "Retreatment"[tiab] OR "hospital mortality"[tiab] OR "operative mortality"[Tiab] OR "peroperative mortality"[Tiab] OR "perioperative mortality"[Tiab] OR "postoperative mortality"[Tiab] OR "Fatal Outcome"[tiab] OR "Survival Rate"[tiab] OR Surgical Wound Infection[tiab OR "Health Status"[tiab] OR "Recovery of Function"[tiab] OR "Patient Safety"[tiab] OR "Safety Management" [tiab] OR "adverse effect"[tiab] OR "adverse effects"[tiab] OR Incident[tiab] OR incidents[tiab] OR Medical Errors [Tiab] OR Medication Errors [Tiab])

Limits: Dutch, English, Humans

Hits: 859

\section{Cochrane Library:}

(Consumer Participation[Mesh] OR patient participation [mesh] OR Pamphlets [Mesh] OR Patient Education as Topic [Mesh] OR Consumer Health Information [Mesh] OR Audiovisual Aids [Mesh] OR Consumer Participation .ti,ab,kw. OR Patient Participation .ti,ab,kw. OR patient involvement.ti,ab,kw. OR consumer involvement .ti,ab,kw. OR Pamphlets .ti,ab,kw. OR Consumer Health Information .ti,ab,kw. OR Educational Technology .ti,ab,kw. OR audiovisual aids .ti,ab,kw. OR user participation. ti,ab,kw. OR client participation .ti,ab,kw. OR citizen participation .ti,ab,kw. OR public participation .ti,ab,kw. OR caregiver participation.ti,ab,kw. OR parent participation .ti,ab,kw. OR relative participation .ti,ab,kw. OR user involvement .ti,ab,kw. client involvement .ti,ab,kw. OR citizen involvement .ti,ab,kw. OR public involvement.ti,ab,kw. OR caregiver involvement. ti,ab,kw. OR parent involvement .ti,ab,kw. OR relative involvement .ti,ab,kw. OR ipad .ti,ab,kw. OR handout* .ti,ab,kw.) AND (Surgery Department, Hospital [Mesh] OR Operating Rooms [Mesh] OR Preoperative Care [Mesh] OR Perioperative Care [Mesh] OR Postoperative Care [Mesh] OR Intraoperative Period [Mesh] OR Postoperative Period [Mesh] OR Perioperative Nursing [Mesh] OR Anesthesia and Analgesia[Mesh] OR Anesthetics[Mesh] OR surger*.ti,ab,kw. OR surgic*.ti,ab,kw. OR Operating Room .ti,ab,kw. OR preoperative .ti,ab,kw. OR perioperative .ti,ab,kw. OR intraoperative .ti,ab,kw. OR postoperative .ti,ab,kw. OR Anaesthesia .ti,ab,kw. OR Anaesthetics .ti,ab,kw. OR Anesthetics .ti,ab,kw. OR Analgesia .ti,ab,kw. OR postanesthesia .ti,ab,kw. OR Recovery room .ti,ab,kw. OR Recovery rooms .ti,ab,kw. OR PACU .ti,ab,kw.) AND (Safety [Mesh] OR Retreatment [Mesh] OR Mortality [Mesh] OR Fatal Outcome [Mesh] OR Survival Rate [Mesh] OR Intraoperative Complications [Mesh] OR Postoperative Complications [Mesh] OR Health Status Disparities [Mesh] OR Safety Management [Mesh] OR Medical Errors [Mesh] OR Medication Errors[Mesh] OR Retreatment .ti,ab,kw. OR hospital mortality .ti,ab,kw. OR operative mortality .ti,ab,kw. OR peroperative mortality .ti,ab,kw. OR perioperative mortality .ti,ab,kw. OR postoperative mortality .ti,ab,kw. OR Fatal Outcome .ti,ab,kw. OR Survival Rate .ti,ab,kw. OR Surgical Wound Infection .ti,ab,kw. OR Health Status .ti,ab,kw. OR Recovery of Function .ti,ab,kw. OR Patient Safety .ti,ab,kw. OR Safety Management .ti,ab,kw. OR adverse effect .ti,ab,kw. OR Incident .ti,ab,kw. OR Medical Errors .ti,ab,kw. OR Medication Errors .ti,ab,kw.)

Hits: 633

\section{Embase}

(exp patient participation/ OR exp preoperative education/ OR exp consumer health information/ OR exp educational technology/ OR audiovisual equipment/ OR preoperative education .ti,ab,kw. OR Pamphlets .ti,ab,kw. OR Consumer Health Information .ti,ab,kw. OR Educational Technology .ti,ab,kw. OR audiovisual aids .ti,ab,kw. OR ipad .ti,ab,kw. OR Handout* .ti,ab,kw OR (( Patient .ti,ab,kw. OR patients .ti,ab,kw. OR stakeholder*.ti,ab,kw. OR consumer .ti,ab,kw. OR user*.ti,ab,kw. OR lay*.ti,ab,kw. or client*.ti,ab,kw. OR citizen*.ti,ab,kw. OR communit*.ti,ab,kw. OR public*.ti,ab,kw. OR caregiver*.ti,ab,kw. OR parent*.ti,ab,kw. OR relative*.ti,ab,kw.) Adj1 (participat*. ti,ab,kw. OR involv*.ti,ab,kw.))) AND (hospital department/ OR exp operating room/ OR exp preoperative care/ OR exp perioperative period/ OR exp postoperative care/ OR exp intraoperative period/ OR exp postoperative period/ OR exp perioperative nursing/ OR exp anesthesia/ OR Operating Room .ti,ab,kw. OR Operating Rooms .ti,ab,kw. OR preoperative.ti,ab,kw. OR preoperative .ti,ab,kw. OR perioperative .ti,ab,kw. OR intraoperative. ti,ab,kw. OR postoperative .ti,ab,kw. OR Anaesthesia .ti,ab,kw. OR Anesthesia.ti,ab,kw. OR Anaesthetics .ti,ab,kw. OR Anesthetics .ti,ab,kw. OR Analgesia.ti,ab,kw. OR postanesthesia .ti,ab,kw. OR Recovery room .ti,ab,kw. OR Recovery rooms.ti,ab,kw. OR PACU .ti,ab,kw. ) AND (exp retreatment/ OR exp patient safety/ OR mortality/ OR exp fatality/ OR exp survival rate/ OR exp peroperative complication/ OR exp health disparity/ OR exp convalescence/ OR medication error/ OR surgical error/ OR therapeutic error/ OR "Retreatment" .ti,ab,kw. OR "hospital mortality" ti,ab,kw. OR "operative mortality" .ti,ab,kw. OR "peroperative mortality" .ti,ab,kw. OR "perioperative mortality" .ti,ab,kw. OR "postoperative mortality" .ti,ab,kw. OR "Fatal Outcome" .ti,ab,kw. OR "Survival Rate" .ti,ab,kw. OR Surgical Wound Infection. ti,ab,kw. OR "Health Status" .ti,ab,kw. OR "Recovery of Function" .ti,ab,kw. OR "Patient Safety" .ti,ab,kw. OR "Safety Management" .ti,ab,kw. OR "adverse effect" .ti,ab,kw. OR "adverse effects" .ti,ab,kw. OR Incident ti,ab,kw. OR incidents .ti,ab,kw. OR medication error .ti,ab,kw.)

Hits: 492

\section{"Back to Top $\uparrow "$}


Appendix 2: Overview of systematic reviews on smoking and alcohol cessation programs.

\begin{tabular}{|c|c|c|c|c|c|c|c|c|}
\hline $\begin{array}{l}\text { Author, } \\
\text { Year, [refer- } \\
\text { ence] }\end{array}$ & $\begin{array}{l}\text { Number of } \\
\text { included } \\
\text { studies }\end{array}$ & $\begin{array}{l}\text { Number of } \\
\text { participants }\end{array}$ & $\begin{array}{l}\text { Included } \\
\text { studies }\end{array}$ & Participants & Intervention & Outcome & Conclusion & $\begin{array}{l}\text { Statistical } \\
\text { significance }\end{array}$ \\
\hline $\begin{array}{l}\text { Möller AM. } \\
2009^{[12]}\end{array}$ & 4 & 627 & RCT's & $\begin{array}{l}\text { Smokers } \\
\text { scheduled } \\
\text { for elective } \\
\text { surgery }\end{array}$ & $\begin{array}{l}\text { Any pre-operative } \\
\text { smoking cessa- } \\
\text { tion intervention } \\
\text { at least } 48 \text { hours } \\
\text { before surgery }\end{array}$ & $\begin{array}{l}\text { Smoking } \\
\text { cessation, } \\
\text { morbidity } \\
\text { and mortality }\end{array}$ & $\begin{array}{l}\text { Smoking } \\
\text { cessation } \\
\text { intervention } \\
\text { is beneficial } \\
\text { for reducing } \\
\text { the incidence } \\
\text { of complica- } \\
\text { tions }\end{array}$ & Not reported \\
\hline $\begin{array}{l}\text { Oppedal K. } \\
2013^{[13]}\end{array}$ & 2 & 69 & RCT's & $\begin{array}{l}\text { Hazardous } \\
\text { drinkers } \\
\text { scheduled for } \\
\text { surgery }\end{array}$ & $\begin{array}{l}\text { All pharmacolog- } \\
\text { ical and psycho- } \\
\text { social } \\
\text { preoperative } \\
\text { alcohol cessation } \\
\text { inter-ventions, giv- } \\
\text { en in relation to a } \\
\text { surgical procedure, } \\
\text { that aimed to stop } \\
\text { or reduce alcohol } \\
\text { consumption pre- } \\
\text { operatively }\end{array}$ & $\begin{array}{l}\text { Primary: } \\
\text { Postoperative } \\
\text { complica- } \\
\text { tions and } \\
\text { mortality } \\
\text { Secondary: } \\
\text { Length of } \\
\text { stay and alco- } \\
\text { hol consump- } \\
\text { tions }\end{array}$ & $\begin{array}{l}\text { Intensive } \\
\text { preopera- } \\
\text { tive alcohol } \\
\text { cessation } \\
\text { interventions } \\
\text { may signifi- } \\
\text { cantly reduce } \\
\text { postoperative } \\
\text { complication } \\
\text { rates. No } \\
\text { effect on } \\
\text { mortality } \\
\text { rates was } \\
\text { found. }\end{array}$ & $\begin{array}{l}\text { Decrease } \\
\text { post-opera- } \\
\text { tive compli- } \\
\text { cation rate: } \\
\text { Odds ratio } \\
0.2295 \mathrm{CI} \\
0.08-0.61, \mathrm{p} \\
=0.004\end{array}$ \\
\hline $\begin{array}{l}\text { Tönnesen, } \\
2009^{[14]}\end{array}$ & 9 & Unknown & $\begin{array}{l}\text { Systematic } \\
\text { review, } \\
\text { RCT's, } \\
\text { clinical } \\
\text { controlled } \\
\text { trials, } \\
\text { descriptive } \\
\text { studies, } \\
\text { experts } \\
\text { and } \\
\text { medical } \\
\text { textbooks }\end{array}$ & $\begin{array}{l}\text { Smokers and } \\
\text { hazardous } \\
\text { drinkers } \\
\text { scheduled for } \\
\text { surgery }\end{array}$ & $\begin{array}{l}6 \text { Smoking and } \\
3 \text { alcohol cessa- } \\
\text { tion intervention } \\
\text { studies }\end{array}$ & $\begin{array}{l}\text { Postoperative } \\
\text { complica- } \\
\text { tions }\end{array}$ & $\begin{array}{l}\text { Intervention } \\
\text { programs } \\
\text { starting 3-8 } \\
\text { weeks before } \\
\text { surgery will } \\
\text { significantly } \\
\text { reduce the } \\
\text { incidence of } \\
\text {-postopera- } \\
\text { tive compli- } \\
\text { cations }\end{array}$ & Not reported \\
\hline $\begin{array}{l}\text { Thomsen } \\
2009^{[15]}\end{array}$ & 11 & 1194 & RCT's & $\begin{array}{l}\text { Smokers } \\
\text { scheduled } \\
\text { for elective } \\
\text { surgery }\end{array}$ & $\begin{array}{l}\text { Interventions } \\
\text { could } \\
\text { include the five } \\
\text { A's (ask, advise, } \\
\text { assess, assist, } \\
\text { arrange), behav- } \\
\text { ioral counseling or } \\
\text { other methods of } \\
\text { counseling and/or } \\
\text { pharmacotherapy }\end{array}$ & $\begin{array}{l}\text { Postoperative } \\
\text { complica- } \\
\text { tions }\end{array}$ & $\begin{array}{l}\text { Preoperative } \\
\text { smoking } \\
\text { cessation } \\
\text { interventions } \\
\text { significantly } \\
\text { reduced the } \\
\text { occurrence of } \\
\text { postoperative } \\
\text { complica- } \\
\text { tions after } \\
\text { surgery }\end{array}$ & $\begin{array}{l}\text { Decrease } \\
\text { post-opera- } \\
\text { tive com- } \\
\text { plication } \\
\text { rate: } \mathrm{RR} \\
0.5695 \% \mathrm{CI} \\
0.41-0.78, \mathrm{P} \\
<0.001\end{array}$ \\
\hline
\end{tabular}

\section{"Back to Top $\uparrow "$}

Ommega Online Publishers

Journal Title: Journal of Anesthesia and Surgery (JAS)

Journal Short Name: J Anesth Surg
Journal ISSN: 2377-1364

E-mail: anestheisa@ommegaonline.com

Website: www.ommegaonline.org 